By ROBERT H. MULLER

\title{
The Selection of Daily Newspapers for a College Library
}

\author{
Dr. Muller is librarian, Bradley Uni- \\ versity.
}

I N SELECTING daily newspapers, the college librarian is usually guided by tradition and by his personal ideas as to what constitutes a well-balanced representation. ${ }^{1} \mathrm{He}$ tries to be fair in his selection by subscribing to the more conservative as well as to the less conservative papers. In the Middle West, if it is a choice between the Chicago Tribune and the Chicago Daily News, he is likely to select both. To demonstrate his lack of bias, he may even add the Chicago Sun and Times, the tabloid in which the Chicago Sun was buried early in 1948 . When it comes to $P M^{*}$ or the Daily $W$ orker, the librarian of a typical mediumsized or small college is likely to be more cautious.

\section{I}

In order to ascertain what newspapers students and faculty wished to see in the library of a fairly typical medium-sized urban college, a questionnaire was submitted to a representative sample of the student body and to all members of the faculty of Bradley University in December 1947. Bradley University had an enrolment of 3128 full-time students and a full-time faculty of 125. It is located in Peoria, a city of over 100,000 population, roughly midway between Chicago and St. Louis, in the "heart" of Illinois.

\footnotetext{
${ }^{1}$ Cf. Lyle, Guy R., The Administration of the

College Library. New York, Wilson, 1945, p. 387.
Now the New York Star.
}

The student sample numbered 373 , or about 12 per cent of the student body. The sample was designed to show the same distribution as the university population; that is, 30 per cent freshman, 43 per cent sophomores, 17 per cent juniors, Io per cent seniors. There were 82 men for every 17 women, which was about the same as the division in the total student body ( $\left.85: 1_{5}\right)$. The sample was obtained through classes in American history, chemistry, philosophy, and sociology.

The faculty questionnaire was returned by 80 out of 125 faculty members $(64$ per cent). Since the responses were anonymous and there was no follow-up, it was impossible to determine how representative the sample was in terms of subject specialization, age, length of residence, etc.; but it seemed large enough to be reliable, and there was no reason to doubt it to be representative of the faculty as a whole.

The following question was asked: "If you could choose only three daily newspapers, which of the following would you like to see in Bradley's library? Indicate your preferences by numbering I, 2, and 3." The list included ten titles. Another question asked what daily newspapers had been regularly or occasionally read by the respondent during the past six months. Table I summarizes the responses, without making a distinction between first, second, and third choices.

The New York Times was selected by more students and more faculty members 
Table I

Newspapers Selected and Read by Students and Faculty

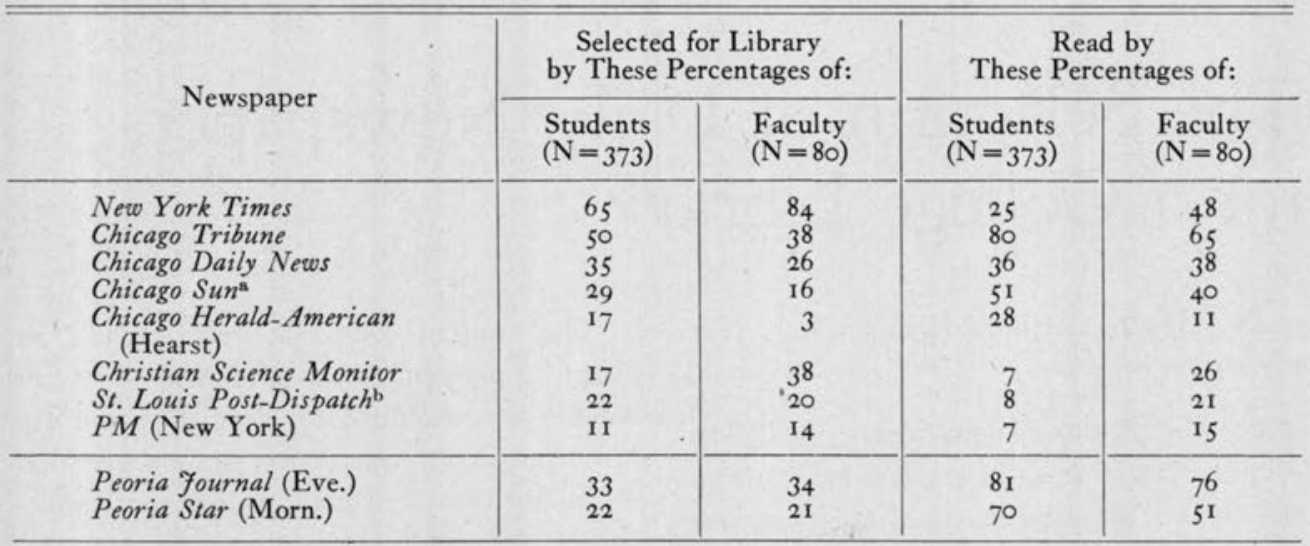

a Merged with the Chicago Times to form the Chicago Sun and Times, after the questionnaire was taken. The Chicago Times, (a tabloid) had been omitted from the list of choices since it was considered to be of negligible appeal in Central Illinois in 1947 , a fact borne out by a survey of newspapers received in lllinois college libraries (Table 6).

b Only one St. Louis paper was included among the choices, largely in order to test the relative cultural dependence of Peoria upon St. Louis as against Chicago.

than was any other paper. The Christian Science Monitor won a higher proportion of votes from the faculty than from students, whereas the opposite was true of the Chicago Tribune and the Chicago Sun. The Chicago Sun had much less appeal than the Chicago Tribune among students as well as faculty. The appeal of the Hearst paper was negligible among the faculty. The Chicago Daily News was moderately popular with both groups. Local papers were chosen by equal proportions of students and faculty, the somewhat more conservative paper (Peoria Star) receiving slightly fewer votes from both groups. The only St. Louis paper included received fewer votes than most Chicago papers, reflecting Peoria's closer ties to Chicago. Very few votes went to $P M$, either because it was relatively unknown or because of its leftist editorial policy.

Comparisons between selections for the library and actual reading were revealing. Apart from the local papers, which, of course, were read more widely than outof-town papers, the Chicago Tribune occupied the highest position for students and faculty. Nevertheless, only a little over one-half of the Tribune readers thought that the Tribune should be in the library. The same tendency was observed for the Chicago Sun and the Chicago HeraldAmerican. The New York Times, and the Christian Science Monitor, on the other hand, showed exactly the opposite tendency, with about twice as many votes for their being selected for the library as the proportions of their actual readers. Such tendencies reflect the high prestige of these latter two papers and also perhaps the fact that what people recommend for others is not necessarily what they prescribe for themselves.

In Tables 2 and 3, actual figures for first, second, and third choices are shown in detail. Among students, the New York Times and the Chicago Tribune were overwhelmingly first choices, whereas among the faculty only the New York Times received a preponderant number of first choices as compared to second and third choices.

To portray relative popularity, a total score was computed for each newspaper as 
Table 2

Students' Choices of Newspapers

$(\mathrm{N}=373)$

\begin{tabular}{|c|c|c|c|c|}
\hline \multirow{2}{*}{ Newspaper } & \multicolumn{3}{|c|}{ Choices } & \multirow{2}{*}{ Total } \\
\hline & Ist & 2nd & $3^{\text {rd }}$ & \\
\hline $\begin{array}{l}\text { New York Times } \\
\text { Chicago Tribune } \\
\text { Chicago Daily News } \\
\text { Peoria Fournal } \\
\text { Chicago Sun } \\
\text { Peoria Star } \\
\text { St. Louis Post-Dispatch } \\
\text { Christian Science Monitor } \\
\text { Chicago Herald-American } \\
\text { PM (New York) }\end{array}$ & $\begin{array}{r}102 \\
78 \\
30 \\
43 \\
20 \\
27 \\
20 \\
15 \\
12 \\
10\end{array}$ & $\begin{array}{l}78 \\
64 \\
54 \\
4 \mathrm{I} \\
38 \\
30 \\
24 \\
32 \\
3 \mathrm{I} \\
13\end{array}$ & $\begin{array}{l}61 \\
45 \\
44 \\
39 \\
50 \\
26 \\
38 \\
18 \\
20 \\
16\end{array}$ & $\begin{array}{l}241 \\
187 \\
128 \\
123 \\
108 \\
83 \\
82 \\
65 \\
63 \\
39\end{array}$ \\
\hline
\end{tabular}

follows: First choices were multiplied by an arbitrary weight of 3 , second choices by a weight of 2 , and third choices by a weight of $\mathrm{I}$. Adding these product's yielded a total score, on the basis of which the rank order of each newspaper was determined. Table 4 shows the ranks of each newspaper; they reflect popularity among students and faculty. Such a table could serve as a practical aid to college librarians whose duties include the selection of newspaper subscriptions. It shows clearly how student opinion differs from faculty opinion ${ }^{2}$ and what newspapers would be most severely missed if the library carried no subscriptions to them.

It is not implied that such a ranking should automatically dictate the choice of subscriptions. It should merely serve as an operational guide. To be specific, a librarian may be convinced that the Chicago Herald-American or PM is the best newspaper; but in choosing either one, Table 4 will tell him how far his selection deviates from popular opinion. He may not wish to meet popular demand, but in deciding not to meet it, a sample survey as outlined in this paper will indicate the risk he is taking. Such knowledge will be of great value in his public relations program.

${ }^{2}$ Spearman's rank correlation coefficient was $+.8 \mathrm{x}$.

Table 3

Faculty's Choices of Newspapers*

$(\mathrm{N}=80)$

\begin{tabular}{|c|c|c|c|c|}
\hline \multirow{2}{*}{ Newspaper } & \multicolumn{3}{|c|}{ Choices } & \multirow{2}{*}{ Total } \\
\hline & Ist & 2nd & 3 rd & \\
\hline $\begin{array}{l}\text { New York Times } \\
\text { Chicago Tribune } \\
\text { Christian Science Monitor } \\
\text { Peoria Fournal } \\
\text { Chicago Daily News } \\
\text { Peoria Star } \\
\text { St. Louis Post-Dispatch } \\
\text { Chicago Sun } \\
\text { PM (New York) } \\
\text { Chicago Herald-American }\end{array}$ & $\begin{array}{r}33 \\
4 \\
3 \\
6 \\
1 \\
3 \\
1 \\
3 \\
3\end{array}$ & $\begin{array}{r}26 \\
21 \\
19 \\
15 \\
16 \\
9 \\
4 \\
7 \\
6 \\
2\end{array}$ & $\begin{array}{r}8 \\
6 \\
8 \\
6 \\
4 \\
5 \\
11 \\
3 \\
2\end{array}$ & $\begin{array}{l}67 \\
31 \\
30 \\
27 \\
21 \\
17 \\
16 \\
13 \\
11 \\
2\end{array}$ \\
\hline
\end{tabular}
choices.

* When a respondent failed to indicate preferences among his three choices, all his selections were counted as second 
Table 4

Newspaper Selections Ranked by Weighted Score Totals*

\begin{tabular}{l|c|c}
\hline \hline \multirow{2}{*}{ Newspaper } & \multicolumn{2}{|c}{ Rank } \\
\cline { 2 - 3 } & Students & Faculty \\
\hline New York Times & I & I \\
Chicago Tribune & 2 & 3 \\
Peoria Fournal & 3 & 2 \\
Chicago Daily News & 4 & 5 \\
Chicago Sun & 5 & 7 \\
Peoria Star & 6 & 6 \\
St. Louis Post-Dispatch & 7 & 9 \\
Christian Science Monitor & 8 & 4 \\
Chicago Herald-American & 9 & 10 \\
PM & 10 & 8 \\
\hline
\end{tabular}

* A first choice received a weight of 3 ; a second choice a weight of $2 ;$ a third choice a weight of $x$. Score totals reflect degree of popularity.

\section{II}

There is always a strong temptation to base recommendations and policies on what other institutions are doing. To show how closely such external evidence agrees with the evidence gathered from the kind of opinion survey described in the first part of this paper, the subscription lists of a sample of four-year colleges accredited by the North Central Association were studied. Of the 28 Illinois colleges that were asked to submit their lists, 25 responded. The average number of subscriptions carried by the group was 5 (both mean and median). ${ }^{3}$

The distribution is shown in Table 5 . This table excludes specialized dailies (such as the Drover's Journal or the Chicago Journal of Commerce) and foreign-language newspapers, but includes local newspapers of the town in which a particular college is located. ${ }^{4}$

Table 6 indicates for each newspaper how many Illinois college libraries were receiving it. When studying this table, it should be borne in mind that not all the colleges

3 This figure is much smaller than the averages obtained in the surveys by Gable. (Gable, J. H., Manual of Serials Work. Chicago, American Library Association, 1937, pp. 176-77.)

4 There was one atypical college which subscribed to a large number of local papers of towns in its region; these local papers were not counted.
Table 5

Frequencies of Newspaper Subscriptions . $n$ 25 Colleges in Illinois

\begin{tabular}{|c|c|}
\hline $\begin{array}{c}\text { Number of } \\
\text { Daily } \\
\text { Newspapers } \\
\text { Received }\end{array}$ & $\begin{array}{l}\text { Number of } \\
\text { Libraries }\end{array}$ \\
\hline $\begin{array}{c}0 \ldots \\
1-4 \ldots \\
5^{-} 6 \ldots \\
7^{-1} 3 \ldots\end{array}$ & $\begin{array}{l}\ldots \\
\ldots\end{array}$ \\
\hline Total. & $\ldots .25$ \\
\hline
\end{tabular}

are located close to Chicago, and that colleges in Southern Illinois are more likely to receive St. Louis papers than those in northern sections, whereas at least one Chicago paper is likely to be received by almost every college in Illinois.

Table 6

Distribution of Newspaper Subscriptions in 22* Colleges in Illinois

\begin{tabular}{cc}
\hline Newspaper & $\begin{array}{c}\text { Number of } \\
\text { Colleges } \\
\text { Receiving }\end{array}$ \\
\hline
\end{tabular}

New York Times................. I9

Christian Science Monitor........... I7

Chicago Tribune................... 16

Chicago Sun ................... I5

Chicago Daily News................ I4

St. Louis Post-Dispatch............ 9

PM................... 4

St. Louis Globe-Democrat. ........... ${ }_{2}^{4}$

New York Herald-Tribune.............. ${ }_{2}$

Chicago Herald-American............ I

Washington Post................... I

Illinois State Fournal (Springfield)..... I

Des Moines Register............... I

Dallas News................. I

* The total number of responding libraries was 25 . of which 3 carried no subscriptions to newspapers (cf. Table 5 ).

Frequencies for the first five titles are so similar that no reliable conclusions as to relative popularity can be drawn. There appears no sharp discrepancy between Table 6 and Table 4, except with regard to the Christian Science Monitor, which is highly 
esteemed by the faculty and is received, probably as a gift, by nearly all libraries, despite its low popularity among students.

The survey of newspaper subscriptions in Illinois college libraries revealed several additional facts: (I) The New York Herald-Tribune, received by two libraries, was taken in addition to, rather than as a substitute of, the New York Times. (2) The only college subscribing to Hearst's Chicago Herald-American received also all the other Chicago dailies. (3) The St. Louis Post-Dispatch was more popular than the St. Louis Globe-Democrat. (4) Most libraries receiving the Chicago Sun also received the Chicago Tribune. There were two colleges, however, where only the Chicago Tribune was subscribed to, and one college where only the Chicago Sun was received. (5) Of the four libraries receiving $P M$, three subscribed to eight additional dailies each, which indicates that such luxury can apparently be afforded only in the more prosperous libraries.

The value of the public opinion approach to newspaper selection can be seen most clearly when studying institutions that receive only four or fewer than four nonlocal newspapers. College A received only the New York Times; College B, the New York Times, the Christian Science Monitor, and PM; College C, the Christian Science Monitor and the Chicago Sun; College D, the New York Times, the Christian Science Monitor, the Chicago Daily News, and the Chicago Tribune; College E, only the Chicago Tribune and Chicago Sun. In all these cases, the question arises as to the soundness of the selection in terms of what the students and the faculty want. An opinion survey might help to provide an answer.

\section{III}

Several studies have shown that most adults read in order to reinforce their predispositions. ${ }^{5}$ They do not usually read newspapers to have themselves converted to a new point of view. If a college library is to gain the support of its constituents, it must necessarily provide opportunities for reinforcement of whatever view is represented among students and faculty. But what of education? Is a college not supposed to expose the student only to the best and to shield him from the worst? To such questions there are no easy answers. College teachers would have to be in agreement as to what is good and what is worthless. They would also have to decide whether exposing the young to disapproved ideas is dangerous, or whether such exposure might not be a useful device for encouraging students to exercise and train their critical abilities.

It seems that the most desirable type of education permits the student to make up his own mind. Indoctrination is effective only on the surface. In a democracy we should vigorously oppose any deliberate blocking of the channels of communication. A college library should foster an atmosphere of impartiality and free inquiry.

As to the practical problem of selecting newspapers the college librarian should be guided primarily by what students and faculty want and by what they believe is good for them. Such preferences can be objectively ascertained, as was demonstrated in Part I of this paper. In addition, if funds permit, he should use his good judgment in providing as wide a selection of different editorial slants as possible to meet the needs of minority groups and to expose students to publications they may otherwise never have an opportunity to read.

\footnotetext{
5 Cf. Waples, Douglas, and others. What Reading Does to People. Chicago, University of Chicago Press, 1942.
} 